\title{
東京医科大学病院における治験エントリーに対する 新聞募集広告の影響
}

$\begin{array}{llllll}\text { 佐 藤 友 枝* } & \text { 松 村 正 史* } & \text { 島 村 宣 江* } \\ \text { 竹 内 弥 生* } & \text { 藤 塚 一 行* } & \text { 奥 山 } & \text { 清* } \\ \text { 細 田 順 一* } & \text { 能登谷 洋 子* } & & & \end{array}$

\section{【目的】}

1998 年 4 月より新 GCP が完全実施になって以 降、治験に参加する被験者が減少していると言わ れている。そうした中、99 年に厚生労働省が広

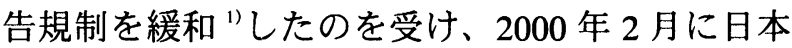
で初めて新聞広告による治験参加者募集が行わ れ、現在までに数多くの治験で広告が行われた。

当院では、5つの新聞募集広告の治験に CRC(治 験コーディネーター) を導入して実施した。今回、 この 5 治験が終了したので、治験エントリーに対 する新聞募集広告の影響について調査したので報 告する。

\section{【方法】}

抗うつ薬 (治験 $\mathrm{A}, \mathrm{E}$ )、脳梗塞後遺症治療薬 (治験 B)、片頭痛治療薬 (治験 C)、アルツハイマー治 療薬 (治験 D) の 5 治験について、広告実施から工 ントリー終了までの治験参加状況などの実態を調 查、分析した。また、治験実施率について、新聞 募集治験と従来の治験とを終了報告書より調查 し、検討した。

\section{【結果】}

今回 5 治験の問い合わせセンターより紹介された 全患者数は 225 名、この内連絡のあった患者数は 151 名、受診した患者数は 101 名、エントリーで

* 東京医科大学病院治験管理室

于 160-0023 東京都新宿区西新宿 6-7-1
きた患者数は 66 名であった。連絡のあった患者 の治験参加率は約 44\%であった。受診のなかっ た患者 50 名の理由は、キャンセル 15 名、薬物ア レルギー 10 名、体調不良で受診できないが 5 名、 プラセボに不安ありが 3 名、受信日の都合がつか ないが 3 名などであった。（Fig）

来院患者に対する治験別の参加率は、治験 $\mathrm{D}, \mathrm{E}$ でそれぞれ 50\%,38\%と低かった。エントリーで きない理由は選択基準に入らないが 11 名、除外 基準に抵触が 3 名、プラセボに不安が 1 名などで あった。

5 治験の時間的な症例エントリーの推移は、各 治験とも募集広告実施後 $1 \sim 3$ ケ月でほぼ目標症 例数に達することができた。契約症例に対する実 施率は、平成 $9 \sim 11$ 年度の治験全体で $71 \%$ であ ったのに対し、広告治験では 93\%と高い実施率 であった。同意取得率も高く、全体で 71 名の患 者に説明を行い、5 名が同意に至らなかった。同 意に至らなかった理由としては、通院が困難、効 果に不安などであった。

\section{【考察】}

今回の 5 治験の新聞広告による参加募集は、CRC が関与することにより受診前に患者情報収集及び スクリーニングができ、受診がスムーズに行えた。 しかし、短期間に多くの患者が集中するため医療 機関側の負担が大きいと考える。連絡のあった患 者で治験参加に至らなかった患者が、全体で 85 名いたことから、治験問い合わせセンターでのよ 


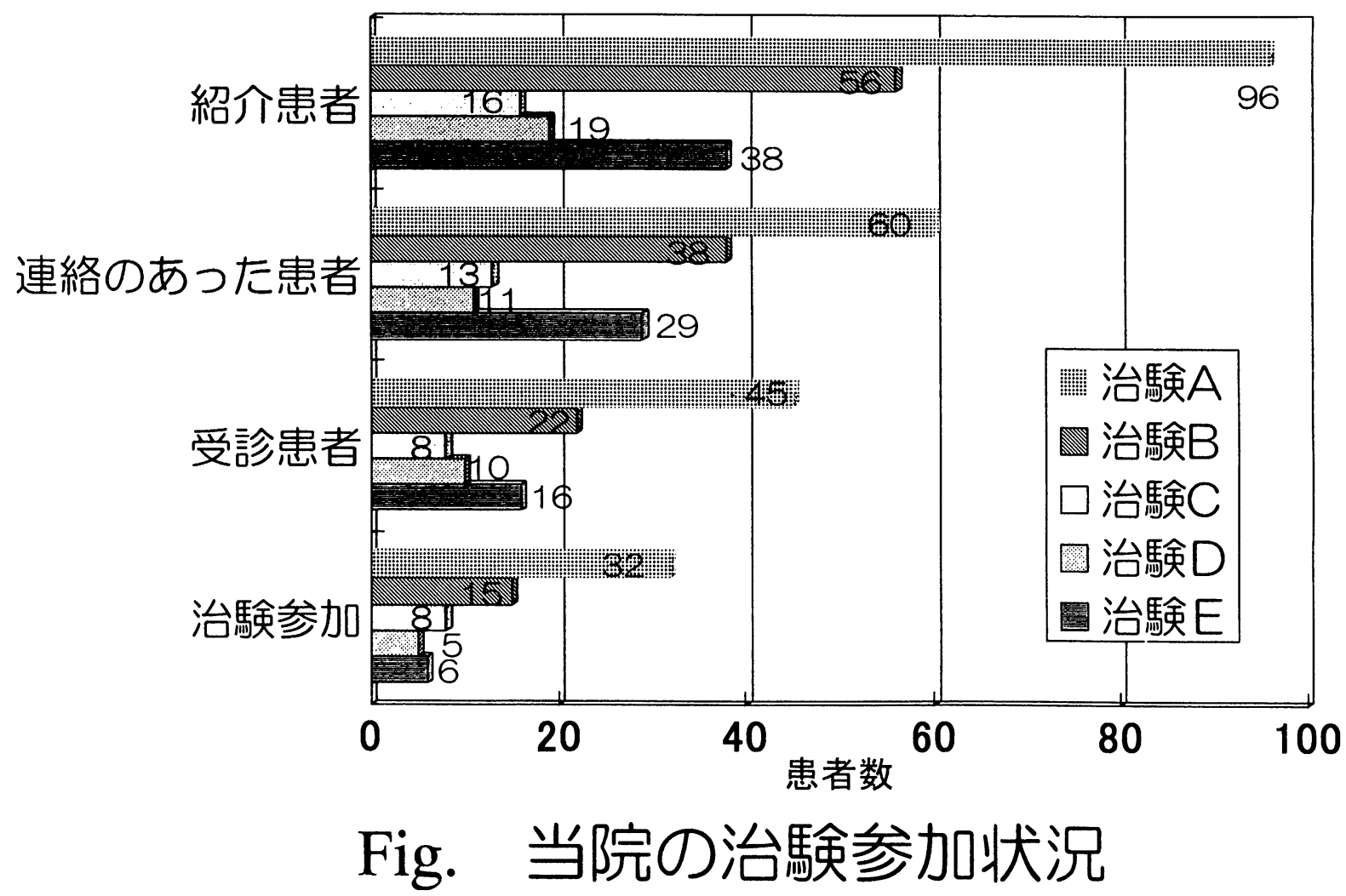

り的確な情報提供とスクリーニングが必要と考え る。

来院患者に対する参加率について 2 治験が低か つた理由として、選択・除外基準に抵触する患者 が多かったことから、選択・除外基準が厳しかっ たことが考えられる。同意取得率については、二 重盲検試験とオープン試験に差はなかった。これ は問い合わせセンターでの情報提供により、患者 が既に承知していたためと思われる。また、医師 の判断により不参加となった患者は、全体で 30 名あったが治験参加できなかった患者への対応も 大切であると考える。当院では、来院しても治験 参加に至らなかった患者の初診料等の医療費を、 治験依頼者の負担としている ${ }^{2)}$ 。
新聞による治験参加募集は、短期間で目標症例 をエントリーできることから、今後、この方法を 採用する治験依頼者が増加することが考えられ る。また、このような治験に対しては、CRC の 関与が不可欠と考える。

\section{【文献】}

1）厚生省医薬安全局監視指導課：治験に係る被 験者募集の情報提供の取り扱い。医薬監第 65 号 (1999年 6 月 30 日)

2）松村正史, 佐藤友枝, 島村宣江ほか：新聞広 告の治験参加募集における当院応需体制と問 題点. 日病薬誌, $37: 365-367$ (2001). 